\title{
Folate absorption from folate-fortified and processed foods using a human ileostomy model
}

\author{
Cornelia M. Witthöft ${ }^{1}$, Karin Arkbåge ${ }^{1}$, Madelene Johansson ${ }^{1}$, Eva Lundin ${ }^{2}$, Gerd Berglund ${ }^{3}$, \\ Jie-Xian Zhang ${ }^{3}$, Hans Lennernäs ${ }^{4}$ and Jack R. Dainty ${ }^{5}$ \\ ${ }^{1}$ Department of Food Science, Swedish University of Agricultural Sciences, P.O. Box 7051, SE-75007 Uppsala, Sweden \\ ${ }^{2}$ Department of Medical Biosciences/Pathology, University of Umeå, SE-90185 Umeå, Sweden \\ ${ }^{3}$ Nutritional Research, Department of Public Health and Clinical Medicine, University of Umeå, SE-90187 Umeå, Sweden \\ ${ }^{4}$ Department of Biopharmaceutics and Pharmacokinetics, University of Uppsala, BMC, P.O. Box 580, SE-75123 Uppsala, Sweden \\ ${ }^{5}$ Institute of Food Research, Norwich Research Park, Colney, Norwich NR4 7UA, UK
}

(Received 16 December 2004 - Revised 29 August 2005 - Accepted 11 September 2005)

\begin{abstract}
Data on folate absorption from food from validated human studies using physiological folate doses are still needed to estimate dietary requirements and to formulate recommendations. The aim of the present work was to study the effects from fortified and processed foods on folate absorption in ileostomy volunteers ( $n$ 9) using the area under the plasma concentration curve (AUC) and kinetic modelling. Using a standardized single-dose protocol, dairy products fortified with a candidate fortificant (6S)-5-methyltetrahydrofolate $\left((6 \mathrm{~S})-5-\mathrm{CH}_{3}-\mathrm{H}_{4}\right.$ folate), folic acid-fortified bread and a dessert crème containing natural yeast folate polyglutamates were compared with folate supplements. Absorbed folate was estimated by AUC and a kinetic model, and non-absorbed folate by ileostomal folate excretion. Median apparent absorption from test foods ranged from 55 to $86 \%$. Added folate-binding proteins (FBP) significantly reduced folate absorption from dairy products, as in the absence of FBP, AUC-dose-corrected ratios were increased and ileal folate excretion decreased. After in vivo gastrointestinal passage of dairy products containing FBP, up to $43 \%$ of the ingested FBP was found in ileostomal effluent. Folate absorption was similar for (6S)-5- $\mathrm{CH}_{3}-\mathrm{H}_{4}$ folate fortificant from fermented milk and for folic acid from fortified bread. Folic acid, ingested as food fortificant in bread, was significantly less absorbed compared with an isolated supplement. We conclude that all tested foods were suitable matrices for folate fortification. However, dairy products, fortified with the new candidate fortificant (6S)-5- $\mathrm{CH}_{3}-\mathrm{H}_{4}$ folate, are suitable if no active $\mathrm{FBP}$ is present.
\end{abstract}

(6S)-5-Methyltetrahydrofolate/folic acid: Folate-binding proteins: Fortified foods: Human folate absorption

An optimal folate status is linked to several health-protective effects, e.g. diminished risk for neural tube defects (Honein et al. 2001; Liu et al. 2004) and spontaneous abortions (George et al. 2002), decreased risk of occlusive vascular diseases (Wald et al. 2002) and improved cognitive or mental functions (Seshadri et al. 2002). These reported health benefits have led to increased folate intake recommendations in the USA and some European and Nordic countries (Yates et al. 1998; Becker et al. 2004).

Information about the extent to which certain foods could contribute to increased folate intake is still incomplete. However, some in vitro and in vivo trials aimed to determine the effects of food matrix on folate absorption, e.g. folic acid-fortified cereal-based foods (Pfeiffer et al. 1997; Malinow et al. 1998; Johansson et al. 2002) or dairy products which contain folate-binding proteins (FBP; Arkbåge et al. 2003; Verwei et al. 2003). Different human models have been used to determine long-term (Malinow et al. 1998; Johansson et al. 2002;
Vahteristo et al. 2002) or short-term (Pfeiffer et al. 1997; Prinz-Langenohl et al. 1999; Finglas et al. 2002; Konings et al. 2002; Witthöft et al. 2003) folate bioavailability or absorption. Long-term protocols are tedious, and also most short-term protocols have certain requirements and limitations as reviewed elsewhere (Witthöft et al. 1999; Gregory, 2001), e.g. lack of sensitivity demanding high test doses or presaturation of volunteers' body stores as recommended for dual-label stable-isotope protocols (Pfeiffer et al. 1997; Rogers et al. 1997). The area under the plasma concentration curve (AUC) technique (Prinz-Langenohl et al. 1999; Konings et al. 2002) is commonly used to estimate folate absorption by comparing a single oral dose of test food with a known dose of a pharmaceutical folate preparation. This concept was questioned as it was hypothesized that oxidized folic acid and reduced folates have different sites of initial metabolism resulting in a greater liver sequestering of folic acid (Wright et al. 2003).

\footnotetext{
Abbreviations: AUC, $\mathrm{AUC}^{0 \rightarrow 600}$, area under the (plasma concentration) curve, superscript time range (in min); $C_{20}$, plasma folate concentration, subscript defines time (in min); FBP, folate-binding proteins; $(6 \mathrm{~S})-5-\mathrm{CH}_{3}-\mathrm{H}_{4}$ folate, $(6 \mathrm{~S})-5$-methyltetrahydrofolate; $t, t_{20}$, time (point), subscript defines time (in min) of folate concentration in plasma.

* Corresponding author: Dr Cornelia M. Witthöft, fax +46 1867 2995, email Cornelia.Witthoft@lmv.slu.se
} 
The present study was carried out to determine effects from differently fortified and processed foods on folate absorption using the AUC technique and a new kinetic modelling method (Kok et al. 2004; Wright et al. 2005) in human ileostomy volunteers and forgoing body store presaturation (Witthöft et al. 2003). Test foods were differently processed dairy and cereal products, which were fortified with folic acid or a new candidate fortificant (6S)-5-methyltetrahydrofolate $\left((6 \mathrm{~S})-5-\mathrm{CH}_{3}-\mathrm{H}_{4}\right.$ folate) or natural yeast folate polyglutamates. Furthermore, effects from dairy FBP on folate absorption and the fate of FBP during in vivo gastro-intestinal passage were studied.

\section{Material and methods}

\section{Subjects}

Nine subjects were recruited (eight males, one female), apparently healthy based on routine haematological and biochemical measurements and a physical examination. They had a mean age of 62 (SD 9.3, range 51-79) years, a mean BMI of 28.9 (SD 4.3 , range $22.6-38.4$ ) $\mathrm{kg} / \mathrm{m}^{2}$, were non-smokers, and did not use any medication or vitamin supplements affecting folate metabolism. They underwent proctocolectomy 1237 years earlier as a result of ulcerative colitis with a maximal resection of $5-10 \mathrm{~cm}$ (except one volunteer: $25 \mathrm{~cm}$ ) of the distal ileum and possessed a conventional well-established ileostomy with no signs of inflammation. Volunteers were screened for fasting serum folate, serum cobalamin and erythrocyte folate concentrations to ensure normal folate and vitamin $B_{12}$ status. The protocol was approved by the Ethical Committee of Umeå University Hospital.

\section{Study design}

All volunteers underwent nine independent study days each 2-4 weeks apart in random order. They received, after overnight fast, either a single dose of test food or a pharmaceutical preparation of the naturally occurring diastereoisomer (6S)-5methyltetrahydrofolate ((6S)-5- $\mathrm{CH}_{3}-\mathrm{H}_{4}$ folate) or folic acid (Table 1). On one day they received no folate to allow for estimation of baseline folate excretion into stomal effluent. During the several months' long trial, volunteers' folate status was standardized by presaturation of body stores with a daily dose of $0.96 \mathrm{mg}$ folic acid from day 9 to day 2 prior to each study day (Witthöft et al. 2003). A standardized low-folate and low-fat lunch (Witthöft et al. 2003) was consumed at $4 \mathrm{~h} 5 \mathrm{~min}$ post-dose, providing $2556 \mathrm{~kJ}, 13.6 \mathrm{~g}$ fat and $18.1 \mu \mathrm{g}$ folate. A snack of $8 \mathrm{~g}$ unsalted rice-cake and $15 \mathrm{~g}$ pasteurized apple crème, providing $163 \mathrm{~kJ}, 0 \cdot 2 \mathrm{~g}$ fat and $3.4 \mu \mathrm{g}$ folate was consumed at $7 \mathrm{~h} 5 \mathrm{~min}$ post-dose.

Table 1. Pharmaceutical preparations and test foods

\begin{tabular}{|c|c|c|c|}
\hline Treatment & & Folate dose/portion* & Further details \\
\hline 1 & $\begin{array}{l}\text { Intramuscular } \\
\text { injection }\end{array}$ & $\begin{array}{l}194-266 \mu \mathrm{g}(422-579 \mathrm{nmol}) \dagger \\
5-\mathrm{CH}_{3}-\mathrm{H}_{4} \text { folate }\end{array}$ & $\begin{array}{l}\text { Injection solution ( } 1 \mathrm{ml} \text { ) prepared from (6S)-Ca-5- } \mathrm{CH}_{3}-\mathrm{H}_{4} \\
\text { folate (Merck Eprova AG, Schaffhausen, Switzerland) } \\
\text { according to Witthöft et al. (2003). }\end{array}$ \\
\hline $\mathrm{O}$ & Pharmaceutical preparation & $192 \mu \mathrm{g}(418 \mathrm{nmol})(6 \mathrm{~S})-5-\mathrm{CH}_{3}-\mathrm{H}_{4}$ folate & Gelatine capsule by Merck Eprova AG. \\
\hline C & Pharmaceutical preparation & $199 \mu \mathrm{g}(451 \mathrm{nmol})$ folic acid & Gelatine capsule by Merck Eprova AG. \\
\hline$U$ & Fermented milk & $\begin{array}{l}187-234 \mu \mathrm{g}(406-509 \mathrm{nmol}) \\
(6 \mathrm{~S})-5-\mathrm{CH}_{3}-\mathrm{H}_{4} \text { folate }\end{array}$ & $\begin{array}{l}\text { Commercial fermented milk product (Filmjölk }{ }^{\circledR} \text {; } \\
\text { Arla Foods, Stockholm, Sweden; } 0.5 \% \text { fat), addition } \\
\text { of }(6 S)-C a-5-\mathrm{CH}_{3}-\mathrm{H}_{4} \text { folate injection solution } 30 \mathrm{~min} \\
\text { prior to consumption; } 400 \mathrm{~g} / \text { portion. }\end{array}$ \\
\hline $\mathrm{F}$ & Fermented milk with FBP & $\begin{array}{l}180-205 \mu \mathrm{g}(392-445 \mathrm{nmol}) \ddagger \\
(6 \mathrm{~S})-5-\mathrm{CH}_{3}-\mathrm{H}_{4} \text { folate }\end{array}$ & $\begin{array}{l}\text { Commercial fermented milk product } \\
\text { (Filmjölk }{ }^{\circledR} ; \text { Arla Foods; } 0.5 \% \text { fat), addition of } \\
\text { (6S)-Ca-5- } \mathrm{CH}_{3}-\mathrm{H}_{4} \text { folate injection solution and whey } \\
\text { protein concentrate WPC } 65 \text { (Arla Foods) } 30 \text { min prior } \\
\text { to consumption; providing } 156-442 \text { nmol FBP } / 400 \mathrm{~g} \\
\text { portion. }\end{array}$ \\
\hline$P$ & Pasteurized milk with FBP & $249 \mu \mathrm{g}(542 \mathrm{nmol})(6 \mathrm{~S})-5-\mathrm{CH}_{3}-\mathrm{H}_{4}$ folate & $\begin{array}{l}\text { Pasteurized skimmed milk ( } 0.5 \% \text { fat) with strawberry } \\
\text { taste, fortified with } 262 \mathrm{nmol} \text { FBP/portion by addition of } \\
\text { whey protein concentrate, WPC } 65 \text { (Arla Foods). Prior } \\
\text { to consumption, the milk was defrosted in a refrigerator } \\
\text { overnight and mixed ( } 400 \mathrm{~g} / \text { portion). }\end{array}$ \\
\hline B & Bread & $217 \mu \mathrm{g}(491 \mathrm{nmol})$ folic acid & $\begin{array}{l}\text { Wheat bread, fortified with folic acid (Merck Eprova), } \\
\text { baked by Cerealia (Järna, Sweden), stored at }-20^{\circ} \mathrm{C} \text {. } \\
\text { The bread was thawed in a refrigerator overnight, the } \\
\text { crust removed and portions of } 50 \mathrm{~g} \text { weighed out } 20 \mathrm{~min} \\
\text { prior to consumption, providing } 12 \mu \mathrm{g}(26 \mathrm{nmol}) \\
\text { endogenous } 5-\mathrm{CH}_{3}-\mathrm{H}_{4} \text { folic acid/portion. }\end{array}$ \\
\hline Y & Yeast crème & $\begin{array}{l}68-75 \mu \mathrm{g}(147-162 \mathrm{nmol}) \text { yeast } \\
5-\mathrm{CH}_{3}-\mathrm{H}_{4} \text { folate polyglutamates }\end{array}$ & $\begin{array}{l}\text { Lemon mousse 'fresta' (citronfromage; Ekströms, } \\
\text { Procordia Food, Eslöv, Sweden) with yeast flakes } \\
\text { (Edelhefe-Flocken auf Melasse Basis, Tartex + Dr } \\
\text { Ritter GmbH, Freiburg, Germany); portions (about } \\
170 \mathrm{~g} \text { ) were prepared 30-45 min prior to consumption. }\end{array}$ \\
\hline
\end{tabular}


Folate absorption was estimated by plasma AUC and a kinetic model from venous blood samples collected $10 \mathrm{~min}$ predose and at 20, 40, 60, 90, $120 \mathrm{~min}$ and 3, 4, 6, 8 and $10 \mathrm{~h}$ post-dose. Non-absorbed folate was estimated from folate excretion into stomal effluent samples, collected every second hour over $10 \mathrm{~h}$ post-dose. Urine samples from spontaneous bladder emptying during $10 \mathrm{~h}$ post-dose were used to ensure that ingested doses did not exceed the kidney threshold. Detailed information of sample collection and storage is given elsewhere (Witthöft et al. 2003).

\section{Sample pretreatment for folate analysis}

Procedures for extraction and purification of plasma and ileostomy samples by strong anion exchange solid-phase extraction and urine samples by affinity chromatography using bovine FBP (Scripps Laboratories, Cincinnati, OH, USA) are described elsewhere (Witthöft et al. 2003). Individual urine samples derived from each subject were pooled beforehand for each test day. Procedures for extraction, deconjugation using hog kidney acetone powder (Sigma Chemical Co., St Louis, MO, USA) and strong anion exchange solid-phase extraction purification of aliquots from food samples (dairy products $5 \mathrm{~g}$, dessert crème with yeast $3.5 \mathrm{~g}$, freeze-dried homogenized lunch and snack samples $2 \mathrm{~g}$ ) have been described earlier (Witthöft et al. 2003). To ensure complete deconjugation of folate polyglutamates in the yeast dessert crème, rat serum (Scanbur, Sollentuna, Sweden) was used according to Patring et al. (2005). Freeze-dried bread samples (2 g) were extracted by a tri-enzyme method using thermostable $\alpha$-amylase (Megazyme International, Cork, Ireland) and protease (Sigma Chemical Co.) according to Johansson et al. (2002).

\section{Folate quantification by HPLC}

5- $\mathrm{CH}_{3}-\mathrm{H}_{4}$ folate content in test foods, pharmaceutical folate preparations and human samples was quantified by reversephase HPLC according to Jastrebova et al. (2003) using a HP 1100 series system equipped with a multi-wavelength detector and a fluorescence detector (Agilent Technologies, Waldbronn, Germany) and a Zorbax SB C8, $150 \times 4.6 \mathrm{~mm}$, $5 \mu \mathrm{m}$ (Agilent Technologies, Palo Alto, CA, USA) column. External calibration $(n 8)$ was carried out using the standards (Eprova AG, Schaffhausen, Switzerland) $(6 \mathrm{~S})-\mathrm{H}_{4}$ folate, (6S)5- $\mathrm{CH}_{3}-\mathrm{H}_{4}$ folate, (6S)-5-HCO-H folate at 290/356 nm (fluorescence detector) and folic acid at 290 and $300 \mathrm{~nm}$ (multiwavelength detector). The limits of quantification were $0.5 \mathrm{ng} / \mathrm{ml}$ for $\mathrm{H}_{4}$ folate, $0.3 \mathrm{ng} / \mathrm{ml}$ for $5-\mathrm{CH}_{3}-\mathrm{H}_{4}$ folate, $4 \mathrm{ng} / \mathrm{ml}$ for $5-\mathrm{HCO}-\mathrm{H}_{4}$ folate and $4 \mathrm{ng} / \mathrm{ml}$ for folic acid. Calibration was linear over a range of $0 \cdot 5-100 \mathrm{ng} / \mathrm{ml}$ for $\mathrm{H}_{4}$ folate, $0 \cdot 3-$ $100 \mathrm{ng} / \mathrm{ml}$ for $5-\mathrm{CH}_{3}-\mathrm{H}_{4}$ folate, $4-200 \mathrm{ng} / \mathrm{ml}$ for $5-\mathrm{HCO}$ $\mathrm{H}_{4}$ folate and $4-200 \mathrm{ng} / \mathrm{ml}$ for folic acid. Intra-assay $\mathrm{CV}$ and relative recoveries for $5-\mathrm{CH}_{3}-\mathrm{H}_{4}$ folate were: $\mathrm{CV}$ of $11.0 \%$ (n 4), 84-105\% recovery in stomal effluent samples and $\mathrm{CV}$ of $6.9 \%(n 4), 86-94 \%$ recovery in plasma samples, including sample preparation and all analytical steps. An inhouse plasma control sample and a milk sample as control for stomal effluent samples were carried through all procedures of sample extraction and purification, resulting in $\mathrm{CV}$ of $6.2 \%$ ( $n$ 41, plasma) and $5.5 \%$ ( $n$ 35, milk) of 5- $\mathrm{CH}_{3}-\mathrm{H}_{4}$ folate concentrations. For folic acid in bread a $\mathrm{CV}$ of $0.9 \%\left(n\right.$ 3) and for $5-\mathrm{CH}_{3}-\mathrm{H}_{4}$ folate in yeast crème a $\mathrm{CV}$ of $7.5 \%(n 3)$ were obtained. Spiking of urine samples with 5- $\mathrm{CH}_{3}-\mathrm{H}_{4}$ folate prior to affinity purification resulted in recoveries of $92-111 \%$ (Witthöft et al. 2003). The day-to-day repeatability for affinity procedures and subsequent $5-\mathrm{CH}_{3}-$ $\mathrm{H}_{4}$ folate quantification resulted in $\mathrm{CV}$ of $6.8 \%$ ( $n 3$, urine) and $4.5 \%$ ( $n 18$, standard solution).

\section{Folate-binding protein quantification}

FBP concentrations in dairy products and stomal effluent samples were determined by a two-site ELISA developed for milk according to Højer-Madsen et al. (1986) with minor modifications as published by Wigertz et al. (1997) using rabbit anti-bovine FBP 24739 (State Serum Institute, Copenhagen, Denmark), FBP calibrant (Central Hospital Hillerød, Hillerød, Denmark) and the software KinetiCalc 4, version 2.5 for Windows (Bio-Tek Instruments, Winooski, VT, USA). A whey protein concentrate, containing $65 \%$ protein (WPC 65; Arla Foods, Götene, Sweden), was included as inhouse reference material into every analysis. The CV between runs did not exceed $15 \%$.

\section{Kinetic and statistical calculations}

Non-absorbed folate from oral doses was estimated by $10 \mathrm{~h}$ post-dose stomal effluent. Absorbed folate was estimated using plasma folate net increase above baseline concentrations (pre-dose). When plasma concentration fell below the predose level, the increment was taken as zero. The (positive) $\mathrm{AUC}^{0 \rightarrow \infty}$ from $t_{0}$ to infinity was calculated for each subject using linear and logarithmic trapezoidal rules for ascending and descending plasma concentrations up to the last timepoint. If folate concentrations at the last blood sampling point $\left(C_{600}\right)$ were still above baseline concentrations $\left(C_{0}\right)$, the AUC beyond $t_{600}$ to infinity (AUC ${ }^{600 \rightarrow \infty}$ ) was extrapolated by log-linear regression analysis using the last three to five plasma concentration data points (choosing the best fit by correlation coefficients).

Relative folate absorption from test foods was compared using AUC-dose-corrected ratios $\left(\mathrm{AUC}_{\mathrm{Testfood}} / \mathrm{Dose}_{\mathrm{Testfood}}\right.$ $((\mathrm{h} \mathrm{ng} / \mathrm{ml})$ per $\mathrm{mol}))$ to normalize for differences in individual test portions.

Apparent folate absorption was estimated by assuming a zero-order absorption process in a single compartment model as described by Kok et al. (2004) using the following equations for all test foods and doses except bread:

$$
\begin{gathered}
C=\frac{M}{V T k}\left(1-\mathrm{e}^{-k\left(t-t_{\text {lag }}\right)}\right) \quad\left(0<t<t_{\max }\right) \\
C=\frac{M}{V T k}\left(1-\mathrm{e}^{-k T}\right) \mathrm{e}^{-k\left(\left(t-t_{\text {lag }}\right)-T\right)} \quad\left(t>t_{\max }\right)
\end{gathered}
$$

where $M$ is the mass of dose absorbed, $t_{\text {lag }}$ is the time during which the plasma enrichment remains at baseline, $t_{\max }$ is the time at which the $5-\mathrm{CH}_{3}-\mathrm{H}_{4}$ folate concentration is a maximum in the plasma, $T$ is the time period for absorption $\left(t_{\max }-t_{\min }\right)$, $C$ is the $5-\mathrm{CH}_{3}-\mathrm{H}_{4}$ folate concentration in the sampled (plasma) compartment, $V$ is the distribution volume of $389 \mathrm{ml} / \mathrm{kg}$ body weight as estimated by Loew et al. (1987) and $k$ is the elimination rate constant. By fitting the above equations to the 
5- $\mathrm{CH}_{3}-\mathrm{H}_{4}$ folate curve (above $C_{0}$ ) over time, $M$ can be calculated. For bread, folate absorption was estimated using the first-order absorption process using the Bateman function:

$$
C=\frac{M K_{\mathrm{a}}}{V\left(K_{\mathrm{a}}-K_{\mathrm{e}}\right)}\left(\mathrm{e}^{-K_{\mathrm{e}} t}-\mathrm{e}^{-K_{\mathrm{a}} t}\right)
$$

where $C$ is the concentration in the sampled compartment, $M$ is the quantity of the dose that is absorbed, $V$ is the distribution volume ( $389 \mathrm{ml} / \mathrm{kg}$ body weight) and $K_{\mathrm{a}}$ and $K_{\mathrm{e}}$ are rate constants of absorption and elimination, respectively. The apparent folate absorption was calculated according to: apparent absorption $(\%)=100 \times M /$ Dose $_{\text {oral }}$.

All calculations were made using Office Excel 97.SR or 2003 SP1 (Microsoft, Redmond, WA, USA).

All statistical analyses were made using Minitab release 13.32 (Minitab Ltd, Coventry, UK). Continuous variables are presented as median and range.

Normal plots of the residuals after fitting linear models showed that log-transformed response variables: AUC-dosecorrected ratios, apparent folate absorption and relative folate excretion with stomal effluent, were approximately normally distributed. Tukey's method was used to control the simultaneous experimental error when performing pair-wise comparison among the treatments. When comparing the intramuscular injection (day I) with the oral treatments Dunnett's method was used to control the simultaneous experimental error. Wilcoxon signed rank test was used to compare effects of treatments $\mathrm{P}$ and $\mathrm{F}$ (see Table 1 for treatments) on relative FBP excretion in ileostomal effluent. A two-sided $P$ value less than 0.05 was considered significant in all analyses.

Nutrient content in standardized low-folate and low-fat lunch and snack was calculated using the software MATs 4.05 (2001) (MATs den flexible, version 2.2; Rudans lättdata, Västerås, Sweden).

\section{Results}

Effects of ingested doses on folate content in plasma, urine and ileostomal effluent

After ingestion of test foods and pharmaceutical preparations containing 5- $\mathrm{CH}_{3}-\mathrm{H}_{4}$ folate and folic acid, post-dose plasma 5- $\mathrm{CH}_{3}-\mathrm{H}_{4}$ folate concentrations increased above fasted baseline levels, but no folic acid was detected. AUC-dose-corrected ratios after intramuscular injection of pharmaceutical (6S)-5- $\mathrm{CH}_{3}-\mathrm{H}_{4}$ folate (day I) were greater than AUC on days $\mathrm{B}, \mathrm{P}, \mathrm{F}(P<0.0001)$ and $\mathrm{U}(P=0 \cdot 0074)$, borderline greater than on day $\mathrm{C}(P=0.0581)$ and similar to days $\mathrm{O}$ $(P=0 \cdot 2898)$ and $\mathrm{Y}(P=0 \cdot 2360)$. When no folate dose was given to volunteers (day $\mathrm{N}$ ), no clear increase and subsequent decrease of plasma $5-\mathrm{CH}_{3}-\mathrm{H}_{4}$ folate concentrations over time was observed. Resulting AUC from $t_{0}$ to $t_{600}$ had for all volunteers a mean size of below $10 \%$ of the AUC on day I (data not shown), and were not taken into account for further calculations. AUC-dose-corrected ratios after ingestion of fermented milk without FBP (U) and yeast dessert crème (Y) were higher compared to the other foods (Table 2). This is similar when estimating apparent folate absorption (Table 3). Apparent absorption from fermented milk without FBP $(\mathrm{U})$ is similar to yeast crème $(\mathrm{Y})(P=0.9891)$, and both are significantly larger than from pasteurized milk with FBP
Table 2. Area under the plasma concentration curve (AUC)-dose-corrected ratios of plasma 5-methyltetrahydrofolate $\left(5-\mathrm{CH}_{3}-\mathrm{H}_{4}\right.$ folate) after absorption of $5-\mathrm{CH}_{3}-\mathrm{H}_{4}$ folate and folic acid from test foods*

(Median values and range for nine subjects)

\begin{tabular}{lcc}
\hline & \multicolumn{2}{c}{$\begin{array}{c}\text { AUC-dose-corrected ratio } \\
((\mathrm{h} \mathrm{ng} / \mathrm{ml}) \text { per mol })\end{array}$} \\
\cline { 2 - 3 } Treatment & Median & Range \\
\hline $\mathrm{I}$ & $0.099^{\mathrm{bd}}$ & $0.034-0.154$ \\
$\mathrm{O}$ & $0.065^{\mathrm{cd}}$ & $0.033-0.121$ \\
$\mathrm{C}$ & $0.075^{\mathrm{cd}}$ & $0.023-0.094$ \\
$\mathrm{U}$ & $0.055^{\mathrm{c}}$ & $0.027-0.087$ \\
$\mathrm{~F}$ & $0.030^{\mathrm{a}}$ & $0.015-0.078$ \\
$\mathrm{P}$ & $0.020^{\mathrm{a}}$ & $0.014-0.035$ \\
$\mathrm{~B}$ & $0.039^{\mathrm{a}}$ & $0.016-0.052$ \\
$\mathrm{Y}$ & $0.143^{\mathrm{b}}$ & $0.056-0.177$ \\
\hline * For details of treatments and procedures, see Table 1 and $\mathrm{p} .182$. \\
a,b,c,d Median values with unlike superscript letters were signifi- \\
\multicolumn{2}{c}{ cantly different $(P<0.05)($ Tukey pair-wise comparison among } \\
\multicolumn{2}{c}{ treatments on log-transformed AUC-dose-corrected ratios). }
\end{tabular}

(P) $(P=0.0137$ and $P=0.0056$, respectively). Apparent folate absorption from bread (B) tends to be larger than from pasteurized milk $(\mathrm{P})(P=0.067)$.

Only small quantities of intact $5-\mathrm{CH}_{3}-\mathrm{H}_{4}$ folate from below 1 to $20 \mu \mathrm{g}$ were excreted into urine during $10 \mathrm{~h}$ post-dose (data not shown). Highest amounts of intact $5-\mathrm{CH}_{3}-\mathrm{H}_{4}$ folate excreted into urine corresponded on three occasions to a maximum of $8 \%$, and on all other occasions to below $5 \%$ of the given dose.

After ingestion of test foods containing $5-\mathrm{CH}_{3}-\mathrm{H}_{4}$ folate, only this folate form was found in stomal effluents and no other folate forms were detected. On day N (baseline), when no folate dose was given, only negligible quantities of 5$\mathrm{CH}_{3}-\mathrm{H}_{4}$ folate $(1 \cdot 6-6 \cdot 0 \mu \mathrm{g} / 10 \mathrm{~h})$ were excreted, being in the same magnitude as absolute $5-\mathrm{CH}_{3}-\mathrm{H}_{4}$ folate excretion after intramuscular injection (I) $(0.7-11.2 \mu \mathrm{g} / 10 \mathrm{~h})$ and after ingestion of folic acid-fortified bread (B) $(1.7-15.4 \mu \mathrm{g} / 10 \mathrm{~h}, n 8$, for one volunteer peak masked). Relative $5-\mathrm{CH}_{3}-\mathrm{H}_{4}$ folate excretion increased significantly after ingestion of all test foods containing $5-\mathrm{CH}_{3}-\mathrm{H}_{4}$ folate $(\mathrm{F}, \mathrm{P}, \mathrm{U}, \mathrm{Y}$ and $\mathrm{O}$, all $P<0.0001)$ compared with the intramuscular injection (I),

Table 3. Apparent 5-methyltetrahydrofolate $\left(5-\mathrm{CH}_{3}-\mathrm{H}_{4}\right.$ folate) and folic acid absorption (\% of dose) from test foods using kinetic modelling of plasma concentration curves*

(Median values and range for nine subjects)

\begin{tabular}{lcc}
\hline & \multicolumn{2}{c}{ Apparent absorption (\%) } \\
\cline { 2 - 3 } Treatment & Median & Range \\
\hline $\mathrm{U}$ & $86^{\mathrm{a}}$ & $29-147$ \\
$\mathrm{~F}$ & $62^{\mathrm{ab}}$ & $37-92$ \\
$\mathrm{P}$ & $55^{\mathrm{b}}$ & $27-64$ \\
$\mathrm{~B}$ & $74^{\mathrm{ab}}$ & $31-159$ \\
$\mathrm{Y}$ & $80^{\mathrm{a}}$ & $37-152$ \\
\hline
\end{tabular}

* For details of treatments and procedures, see Table 1 and p. 182. a,b Median values with unlike superscript letters were significantly different $(P<0.05)$ (Tukey pair-wise comparison among treatments on log-transformed apparent folate absorption). 
being significantly higher on days $\mathrm{P}$ and $\mathrm{Y}$ compared with day $\mathrm{U} \quad(P=0.0214$ and $P=0.0371$, respectively $)$ and day $\mathrm{O}$ ( $P=0.0058$ and $P=0.0111$, respectively) (Table 4). After ingestion of folic acid-fortified bread (B), some folic acid traces up to approximately $17 \mu \mathrm{g} / 10 \mathrm{~h}$ were excreted in stomal effluent, and after pharmaceutical folic acid (C) 1$13 \mu \mathrm{g} / 10 \mathrm{~h}$ were excreted. This is only a rough estimate due to folate concentrations below the limit of quantification in some of the ileostomal fractions.

Effects from dairy processing and presence of folate-binding proteins on folate absorption

The presence of FBP in dairy products affected folate absorption. AUC-dose-corrected ratios were significantly increased on day $\mathrm{U}$ after ingestion of fermented milk without FBP compared to days $\mathrm{F}(P=0.0243)$ and $\mathrm{P}(P=0.0001)$. Median AUC-dose-corrected ratios for both dairy products containing FBP did not differ significantly $(P=0.5877)$. However, apparent folate absorption on day $\mathrm{U}$ was only significantly increased compared to day $\mathrm{P}(P=0.0137)$, but not to day $\mathrm{F}(P=0.6224)$. Plasma results were complemented by data on relative ileostomal folate excretion, which increased significantly on day $\mathrm{P}$ $(P=0.0214)$ compared to day $\mathrm{U}$, but not on day $\mathrm{F}$ $(P=0.7152)$ (Table 4).

After in vivo gastrointestinal passage of dairy products fortified with FBP (P and F), FBP was found in ileostomal effluents (Table 5), being significantly higher on day $\mathrm{P}$ than day $\mathrm{F}$ $(P=0.009)$. On days without FBP ingestion, e.g. days $U$ and $\mathrm{N}$, no FBP was detected in post-dose effluents, as controlled for four volunteers (data not shown).

\section{Effect of ingested folate form on extent of absorption}

Folate absorption by means of AUC-dose-corrected ratios did not differ significantly $(P=0.9940)$ after oral ingestion of pharmaceutical preparations of $(6 \mathrm{~S})-5-\mathrm{CH}_{3}-\mathrm{H}_{4}$ folate $(\mathrm{O})$ and folic acid $(\mathrm{C})$. Also total folate excretion after ingestion of both folate forms was similar. After ingestion of $5-\mathrm{CH}_{3}-$ $\mathrm{H}_{4}$ folate $(\mathrm{O}), 2-74 \mu \mathrm{g} 5-\mathrm{CH}_{3}-\mathrm{H}_{4}$ folate were found in stomal

Table 4. Relative excretion of 5-methyltetrahydrofolate (5- $\mathrm{CH}_{3}-\mathrm{H}_{4}$ folate) (\% of dose) with stomal effluent over $10 \mathrm{~h}$ post-dose*

(Median values and range for nine subjects)

\begin{tabular}{|c|c|c|}
\hline \multirow[b]{2}{*}{ Treatment } & \multicolumn{2}{|c|}{ 5- $\mathrm{CH}_{3}-\mathrm{H}_{4}$ folate excretion (\%) } \\
\hline & Median† & Range \\
\hline I & $2^{a}$ & $0-5$ \\
\hline 0 & $8^{b}$ & $2-39$ \\
\hline U & $7^{\mathrm{b}}$ & $4-25$ \\
\hline $\mathrm{F}$ & $16^{\mathrm{bc}}$ & $5-29$ \\
\hline$P$ & $20^{c}$ & $13-51$ \\
\hline$Y$ & $23^{c}$ & $13-37$ \\
\hline \multicolumn{3}{|c|}{$\begin{array}{l}{ }^{*} \text { For details of treatments and procedures, see Table } 1 \text { and } \mathrm{p} .182 . \\
\dagger \text { Median for } \mathrm{Y}(n \text { 8) as peak for one volunteer masked, median } \\
\text { for I }(n 8) \text { as amount for one volunteer traces only. } \\
\text { a,b,c Median values with unlike superscript letters were significantly } \\
\text { different }(P<0.05) \text { (Tukey pair-wise comparison among treat- } \\
\text { ments on log-transformed relative folate excretion in stomal } \\
\text { effluent). }\end{array}$} \\
\hline
\end{tabular}

Table 5. Relative excretion of folate-binding proteins (\% of dose) with stomal effluent over $10 \mathrm{~h}$ post-dose* (Median values and range for nine subjects)

\begin{tabular}{|c|c|c|}
\hline \multirow[b]{2}{*}{ Treatment† } & \multicolumn{2}{|c|}{ FBP excretion (\%) } \\
\hline & Median & Range \\
\hline $\mathrm{F}$ & $4^{b}$ & $0-32$ \\
\hline $\mathrm{P}$ & $24^{a}$ & $3-43$ \\
\hline \multicolumn{3}{|c|}{$\begin{array}{l}{ }^{*} \text { For details of treatments and procedures, see Table } 1 \text { and } p .182 . \\
\dagger \text { No folate-binding proteins found in ileostomal effluent on other } \\
\text { days (N. U). }\end{array}$} \\
\hline
\end{tabular}

effluent during $10 \mathrm{~h}$ post-dose, and after ingestion of folic acid (C), 3-41 $\mu \mathrm{g}$ 5- $\mathrm{CH}_{3}-\mathrm{H}_{4}$ folate and an additional 1$13 \mu \mathrm{g}$ of folic acid were excreted.

Absorption of different folate forms as fortificant, (6S)-5$\mathrm{CH}_{3}-\mathrm{H}_{4}$ folate monoglutamate in fermented milk (U) compared to folic acid in wheat bread (B) compared to yeast 5- $\mathrm{CH}_{3}-$ $\mathrm{H}_{4}$ folate polyglutamates as 'bio-fortificant' $(\mathrm{Y})$, differed significantly when expressed as AUC-dose-corrected ratios. Y was significantly more absorbed than $\mathrm{U}(P=0 \cdot 0001)$ and than B $(P<0.0001)$, and B significantly less than $\mathrm{U}$ $(P=0 \cdot 0384)$.

After ingestion of folic acid as fortificant within a bread matrix (B), AUC-dose-corrected ratios were significantly smaller $(P=0.0041)$ compared with a supplement $(\mathrm{C})$. Ileostomal folic acid excretion was estimated to be $4-24 \mu \mathrm{g}$ on day $\mathrm{B}$ and $1-13 \mu \mathrm{g}$ on day $\mathrm{C}$. (6S)-5- $\mathrm{CH}_{3}-\mathrm{H}_{4}$ folate given as supplement $(\mathrm{O})$ was similarly absorbed as when given as fortificant in fermented dairy matrix (without FBP, U), based on AUC-dose-corrected ratios $(P=0.7822)$.

\section{Discussion}

Effects of dairy processing and presence of folate-binding proteins on folate absorption

New information on effects of presence of FBP on folate absorption in human subjects was provided by the present study. Plasma results demonstrated that $(6 \mathrm{~S})-5-\mathrm{CH}_{3}-\mathrm{H}_{4}$ folate, a candidate compound for food fortification and the dominant native food folate form, is bioavailable from all tested dairy matrices. Median AUC-dose-corrected ratios are significantly reduced in the presence of FBP (Table 2). Also apparent 5$\mathrm{CH}_{3}-\mathrm{H}_{4}$ folate absorption from pasteurized milk with FBP (P) is smaller than from fermented milk without FBP (U) (Table 3) and conversely relative folate excretion with ileostomal effluent is higher for $\mathrm{P}$ than $\mathrm{U}$ (Table 4). The present findings suggest that FBP is reducing folate absorption. Folate is better absorbed from fermented milk than from pasteurized milk due to the absence of native FBP.

The present study is the first to prove intestinal 'survival' of FBP in man. Using in vitro methods simulating the upper human intestinal tract, Verwei et al. (2003) and Arkbåge et al. (2003) reported that between 0 and $34 \%$ of FBP from the dose was recovered after 'digestion' of milk and yoghurt fortified with (6S)-5- $\mathrm{CH}_{3}-\mathrm{H}_{4}$ folate or folic acid. Interestingly, this reflects our findings in vivo with FBP survival (Table 5). 
Arkbåge et al. (2003) reported a significantly decreased bioaccessibility, from yoghurt fortified with $\mathrm{FBP}$, of both $5-\mathrm{CH}_{3}-$ $\mathrm{H}_{4}$ folate and folic acid. In agreement, we conclude that dairy products might be a suitable matrix for folate fortification if no active FBP is present.

\section{Folate fortificants and supplements}

Folate absorption from pharmaceutical folic acid and (6S)-5$\mathrm{CH}_{3}-\mathrm{H}_{4}$ folate supplements did not differ significantly, but more folic acid was absorbed as a supplement than from a bread matrix (Table 2). However, as median apparent absorption from folic acid-fortified bread was high at $74 \%$ (Table 3 ), bread is a suitable matrix for folic acid fortification. Data from a previous study (Johansson et al. 2002) showed that folic acid fortification of bread results in a significant improvement of volunteers' folate status after just 4 weeks of intervention. Of interest is the comparison of the already-established folic acid fortification practice of cereal-based food with alternative fortificants and matrices, e.g. by using as a new candidate fortificant the biologically active form of $(6 \mathrm{~S})-5-\mathrm{CH}_{3}-\mathrm{H}_{4}$ folate in dairy matrices, or natural yeast folate polyglutamates for 'biofortification'. Folic acid is used as food fortificant because it is inexpensive and relatively stable, but, in contrast to reduced folates, a high intake can delay diagnosis of an underlying vitamin $\mathrm{B}_{12}$ deficiency. Around $80 \%$ of all folate 'fortificants', yeast polyglutamates from dessert crème (Y), (6S)-5$\mathrm{CH}_{3}-\mathrm{H}_{4}$ folate from fermented milk without $\mathrm{FBP}$ (U) and folic acid from bread, were absorbed (Table 3). Median apparent absorption of yeast folate from the dessert crème in the present study ( $86 \%$ ) was much higher than the estimate of folate bioavailability of a yeast drink of $59 \%$ in the intervention study of Hannon-Fletcher et al. (2004). Our HPLC method, allowing quantification of four different folate forms, might have led to an underestimation of the total folate content in that particular test food when other folate forms were present. In theory, this could result in an overestimation of folate absorption. As high folate-producing yeast strains could be an alternative for folate enrichment, future investigation of this interesting matrix is warranted.

\section{Critical appraisal of the ileostomy-area under the curve model: limitations and advantages}

The model enables the direct estimation, by comparison of AUC-dose-corrected ratios and kinetic models, of the extent of folate absorption after ingestion of different test foods.

Some noise in plasma folate concentrations was visible in the form of minor AUC on day $\mathrm{N}$ with no test food application, which may reflect effects from fasting, enterohepatic circulation and ingestion of the standardized low-folate, lowfat meals on plasma folate levels. We decided not to correct for them when interpreting plasma results due to strict standardization of the study protocol (regarding sampling, fasting periods and test food ingestion), as we expect possible confounding effects to be similar on all days. Another possible confounder regarding plasma data is the hepatic first pass effect (Pfeiffer et al. 1997; Rogers et al. 1997). In line with their recommendation, we presaturated, and therefore standardized, volunteers' body stores. Using the plasma AUC approach (Prinz-Langenohl et al. 1999; Konings et al.
2002), folate absorption from a test food is usually estimated by comparison with an oral reference dose of folic acid; but hereby it is not guaranteed that the oral reference dose is completely absorbed. To overcome this problem, the concept of an intramuscular reference dose was developed (Witthöft et al. 2003), where relative absorbed folate from an oral test dose was estimated using a reference dose of $(6 \mathrm{~S})-5-\mathrm{CH}_{3}-\mathrm{H}_{4}$ folate administered by intramuscular injection (day I). Using labelled folate compounds, Wright et al. (2003, 2005) observed concurrent displacement of endogenous (unlabelled) liver folates after an oral folate test dose and hypothesized differences in metabolism of oxidized and reduced folates. It was suggested earlier that different folate forms (oxidized compared to reduced) and administration (oral compared to intravenous injection) could result in different handling in the body (Finglas et al. 2002). This may lead to the conclusion that the quantification of absorbed folate from a test food by comparison with any reference dose might be unsuitable when no labelled compounds are used. Therefore, we decided to avoid estimation of relative folate absorption by a reference dose, but rather determine effects of processed and fortified food on folate absorption by direct comparison of AUCdose-corrected ratios.

Plasma results are complemented by data from ileostomal folate excretion, and estimated absorbed (by AUC) and nonabsorbed (by stomal excretion) folate should in theory amount to approximately $100 \%$ (Witthöft et al. 2003). Overestimation of total recovery could be caused by overestimating plasma AUC due to a bad curve fit when extrapolating or during kinetic modelling, when estimating the distribution volume $V$ using the factor (of $389 \mathrm{ml} / \mathrm{kg}$ body weight) from Loew et al. (1987), which was estimated after a single intravenous dose of oxidized folic acid of pharmacological magnitude. Underestimation of the model's overall recovery can mainly be caused by incomplete collection of ileostomal effluent.

The small quantities of $5-\mathrm{CH}_{3}-\mathrm{H}_{4}$ folate in $10 \mathrm{~h}$ post-dose urine are in line with earlier findings (Pfeiffer et al. 1997; Witthöft et al. 2003). Thus, the given doses can be considered to be of physiological size and that the kidney threshold was not reached.

In conclusion, this new human model was used to compare folate absorption from differently processed and fortified foods. As each volunteer was randomly participating in the nine strictly standardized study days, intra-individual as well as inter-individual comparison of folate absorption was possible. The presented model would be strengthened by combination with stable-isotope techniques, as differentiation of plasma folate deriving from the exogenous dose and from endogenous body stores is of importance when studying folate absorption and elimination kinetics by AUC.

\section{Acknowledgements}

We are most grateful to the volunteers for their enthusiastic participation in the study. The project was funded by the European Union under Key Action 1: Food Nutrition and Health (QLK1-1999-00 576). The gift of (6S)-Ca-5-methyltetrahydrofolate and folic acid pharmaceutical preparations from Merck Eprova AG, Schaffhausen, Switzerland, the preparation of some dairy products by Arla Foods, Stockholm, Sweden and 
bread by Cerealia, Järna, Sweden, the donation of ileostomy bags and accessories by Bristol-Myers Squibb AB, ConvaTec, Bromma, Sweden and financial support by a Druvan grant (Dr P. Håkanssons Foundation, Sweden) are gratefully acknowledged. We thank Irina Boriak, Hanna Åhlin, Barbara Ryan, Veronica Westman, Barbro Åström, Lena Marklund, Maria Jonsson and Jeanette Andersson for skilled technical assistance, and Prof. Margaretha Jägerstad (Swedish University of Agricultural Sciences) and Prof. Göran Hallmans (University of Umeå) for critical evaluation of the manuscript.

\section{References}

Arkbåge K, Verwei M, Havenaar R \& Witthöft C (2003) Bioaccessibility of folic acid and (6S)-5-methyltetrahydrofolate decreases after addition of folate-binding protein to yogurt as studied in a dynamic in vitro gastointestinal model. J Nutr 133, 3678-3683.

Becker W, Lyhne N, Pedersen AN, Aro A, Fogelholm M, Phórsdottir I, Alexander J, Anderssen SA, Meltzer HM \& Pedersen JI (2004) Nordic Nutrition Recommendations 2004 - integrating nutrition and physical activity. Scand J Nutr 48, 178-187.

Finglas PM, Witthöft CM, Vahteristo L, Wright AJA, Southon S, Mellon F, Ridge B \& Maunder P (2002) Use of an oral/intravenous dual-label stable-isotope protocol to determine folic acid bioavailability from fortified cereal grain foods in women. J Nutr 13, 936-939.

George L, Mills JL, Johansson ALV, Nordmark A, Olander B, Granath F \& Cnattingius S (2002) Plasma folate levels and risk of spontaneous abortion. JAMA 288, 1867-1873.

Gregory JF (2001) Case study: folate bioavailability. J Nutr 131, $1376 \mathrm{~S}-1382 \mathrm{~S}$

Hannon-Fletcher MP, Armstrong NC, Scott JM, Pentieva K, Bradbury I, Ward M, Strain JJ, Dunn AA, Molloy AM, Kerr MA \& McNulty H (2004) Determining bioavailability of food folates in a controlled intervention study. Am J Clin Nutr 80, 911-918.

Højer-Madsen M, Hansen SI \& Holm J (1986) Rabbit antibodies against the folate binding protein from cow's milk - production, characterization and use for development of an enzyme-linkedimmunosorbent-assay (ELISA). Biosci Rep 6, 895-905.

Honein MA, Paulozzi LJ, Mathews TJ, Erickson JD \& Wong LYC (2001) Impact of folic acid fortification of the US food supply on the occurrence of neural tube defects. JAMA 285, 2981-2986.

Jastrebova J, Witthöft CM, Grahn A, Svensson U \& Jägerstad M (2003) HPLC determination of folates in raw and processed beetroots. Food Chem 80, 579-588.

Johansson M, Witthöft C, Bruce A \& Jägerstad M (2002) Study of wheat breakfast rolls fortified with folic acid. The effect on folate status in women during a 3-month intervention. Eur J Nutr 41, 279-286

Kok RM, Smith DEC, Dainty JR, van den Akker JT, Finglas PM, Smulders YM, Jakobs C \& de Meer K (2004) 5-Methyltetrahydrofolic acid and folic acid measured in plasma with liquid chromatography tandem mass spectrometry: applications to folate absorption and metabolism. Anal Biochem 326, 129-138.

Konings EJM, Troost FJ, Castenmiller JJM, Roomans HHS, van den Brant PA \& Saris WHM (2002) Intestinal absorption of different types of folate in healthy subjects with an ileostomy. $\mathrm{Br} J$ Nutr 88, 235-242.

Liu S, West R, Randell E, Longerich L, O'Connor K, Scott H, Crowley M, Lam A, Prabhakaran V \& McCourt C (2004) A comprehensive evaluation of food fortification with folic acid for the primary prevention of neural tube defects. BMC Pregnancy Childbirth 4 , 20, http://www.biomedcentral.com/1471-2393/4/20.

Loew D, Eberhardt A, Heseker H \& Kübler W (1987) Zur Plasmakinetik und Elimination der Folsäure. Klin Wochenschr 65, 520-524.

Malinow MR, Duell PB, Hess DL, Anderson PH, Kruger WD, Phillipson BE, Gluckman RA, Block PC \& Upson BM (1998) Reduction of plasma homocyst(e)ine levels by breakfast cereal fortified with folic acid in patients with coronary heart disease. $N$ Engl J Med 338, 1009-1015.

Patring JDM, Jastrebova JA, Hjortmo SB, Andlid TA \& Jägerstad IM (2005) Development of a simplified method for the determination of folates in baker's yeast by HPLC with ultraviolet and fluorescence detection. J Agric Food Chem 53, 2406-2411.

Pfeiffer CM, Rogers LM, Bailey LB \& Gregory IJF (1997) Absorption of folate from fortified cereal-grain products and of supplemental folate consumed with or without food determined using a dual-label stable-isotope protocol. Am J Clin Nutr 66, $1388-1397$.

Prinz-Langenohl R, Brönstrup A, Thorand B, Hages M \& Pietrzik K (1999) Availability of food folate in humans. J Nutr 129, 913-916.

Rogers LM, Pfeiffer CM, Bailey LB \& Gregory JF (1997) A duallabel stable-isotope protocol is suitable for determination of folate bioavailability in humans: evaluation of urinary excretion and plasma folate kinetics of intravenous and oral doses of $\left[{ }^{13} \mathrm{C}_{5}\right]$ and $\left[{ }^{2} \mathrm{H}_{2}\right]$ folic acid. $J$ Nutr 127, 2321-2327.

Seshadri S, Beiser A, Selhub J, Jacques PF, Rosenberg IH, D'Agostino RB, Wilson PWF \& Wolf PA (2002) Plasma homocysteine as a risk factor for dementia and Alzheimer's disease. $N$ Engl J Med 346, 476-483.

Vahteristo L, Kariluoto SM, Bärlund S, Kärkkäinen M, LambergAllardt C, Salovaara H \& Piironen V (2002) Functionality of endogenous folates from rye and orange juice using a human in vivo model. Eur J Nutr 41, 271-278.

Verwei M, Arkbåge K, Havenaar R, Van den Berg H, Witthöft C \& Schaafsma G (2003) Folic acid and 5-methyltetrahydrofolic acid in fortified milk are bioaccessable as determined in a dynamic in vitro gastrointestinal model. J Nutr 133, 2377-2383.

Wald DS, Law M \& Morris JK (2002) Homocysteine and cardiovascular disease: evidence on causality from a meta-analysis. $\mathrm{Br} \mathrm{Med}$ J 325, 1202-1206.

Wigertz K, Svensson UK \& Jägerstad M (1997) Folate and folatebinding protein content in dairy products. J Dairy Res 64, $239-252$.

Witthöft CM, Forssén K, Johannesson L \& Jägerstad M (1999) Folates - food sources, analyses, retention and bioavailability. Scand J Nutr 43, 138-146.

Witthöft CM, Strålsjö L, Berglund G \& Lundin E (2003) A human model to determine folate bioavailability from food - a pilot study for evaluation. Scand J Nutr 47, 6-18.

Wright AJA, Finglas PM, Dainty JR, Hart DJ, Wolfe CA, Southon S \& Gregory JF (2003) Single oral doses of ${ }^{13} \mathrm{C}$ forms of pteroylmonoglutamic acid and 5-formyltetrahydrofolic acid elicit differences in short-term kinetics of labelled and unlabelled folates in plasma: potential problems in interpretation of folate bioavailability studies. Br J Nutr 90, 363-371.

Wright AJA, Finglas PM, Dainty JR, Wolfe CA, Hart DJ, Wright DM \& Gregory JF (2005) Differential kinetic behavior and distribution for pteroylglutamic acid and reduced folates: a revised hypothesis of the primary site of PteGlu metabolism in humans. J Nutr 135, 619-623.

Yates AA, Schlicker SA \& Suitor CW (1998) Dietary reference intakes: the new basis for recommendations for calcium and related nutrients, B vitamins and choline. J Am Diet Assoc 98, 699-706. 